\title{
CHARACTER DEVELOPMENT OF FLORENTINO ARIZA AS SEEN IN GABRIEL GARCIA MARQUEZ'S LOVE IN THE TIME OF CHOLERA
}

\author{
Mala Hernawati
}

\begin{abstract}
INTISARI
Florentino Ariza adalah karakter utama dalam sebuah novel karya Gabriel Garcia Marquez, Love in the Time of Cholera. Karakter utama tersebut mengalami perubahan dari lelaki muda yang polos menjadi seorang lelaki yang tidak senonoh. Perubahan ini disebabkan oleh cintanya pada seorang wanita bernama Fermina Daza. Nasib harus membuatnya menunggu lebih dari setengah abad hingga akhirnya ia mendapatkan cintanya. Artikel ini menghasilkan beberapa kesimpulan. Pertama, Florentino Ariza memenuhi kriteria sebagai perpaduan dari dynamic character dan round character. Kedua, Florentino tergolong dalam kelompok melankolis dan terdapat dua faktor atas perubahan kepribadiannya: mabuk cinta dan godaan dari lingkungannya.
\end{abstract}

Kata kunci: karakter, perkembangan, mabuk cinta, perubahan, kepribadian

\begin{abstract}
Florentino Arriza is the main character in Gabriel Garcia Marquez's novel, Love in the Time of Cholera. This main character experiences the change from an innocent young man to become an indecent man. This change is mainly caused by his love to a woman named Fermina Daza. Destiny makes him wait for more than half a century to finally win her love. This article results in several conclusions. First, Florentino Ariza fits the criteria of the combination of the dynamic and round characters. Second, he belongs to the group of Melancholy. In addition, there are two factors for his personality changes: lovesickness and environmental temptation.
\end{abstract}

Keywords: character, development, lovesickness, change, personality

\section{INTRODUCTION}

Love in the Time of Cholera is written by Gabriel Jose Garcia Marquez, a Nobel Prize winning author, some of whose works are phenomenal. It is one of his best-seller novels. This novel is strongly influenced by the social condition of Columbia around 1980s when cholera spreads out in this South American country. It is originally written in Spanish with the original title El Amor En Los Tiempos Del Colera. It was firstly published in its original version in 1985. Its English version was published in 1988.

This novel is chosen as the object of the study because of several reasons. The characters in this novel are very impressive. Each character is presented with a strong characterization especially the main character, Florentino Ariza. This character is described as someone who is very unpredictable in the story. His effort, his madness, and his patience to wait for his lover for more than half a century are amazing. In addition, the obstacles that the characters face in winning their love and how they dealing with those obstacles are interesting to explore.

This novel has a complexity of themes: love, aging, and death. Below is a statement supporting the complexity of themes in the novel.

Love in the Time of Cholera is an "anatomy" of love. One of its most ingenious portrayals (in an anatomical and a visionary sense) is the growth of love out of the profane envi $\neg$ rons of "convenience." All the meaningless details of everyday life shared by two people bound together (all the un-pleasant smells, degrading tasks, and dulling routines; all the unspoken bitterness and rancor; all the sullenness and 
gloom engendered by unlived possibilities) are unmerci $\neg$ fully catalogued. (http://www/GARCIA/ marquez.htm DOD May 4th 2011,11.55 PM)

As stated above, this novel is an anatomy of love, which means that it presents many elements of love (passion, craziness, affection, relationship etc.) and many kinds of love (requited love, unrequited love, first love, true love etc.). The citation above states that the growth of love out of the normal convention becomes one theme that is strongly found in the story.

Through its plot, this novel is capable of showing the irony that is perhaps considered as a strange happening that is impossible to happen, but which truly happens. The lives of the characters, especially the main character, are far from the ideal life that people used to figure out. Moreover, there are many life lessons that the readers can absorb from this novel especially in how to deal with love.

The discussion in this article is limited to the character of Florentino as one of the major characters. Because the analysis will only focus on the intrinsic elements in the novel, the Objective Approach is considered as the most appropriate approach to be applied in this study.

The Objective Approach is also known as Intrinsic Approach because the primary focus of this approach is on the intrinsic elements of a work of art as stated by Abrams below :

...the 'objective orientation,' which on principle regards the work of art in isolation from all these external points of reference, analyzes it as a self-sufficient entity constituted by its part in their internal relations, and sets out to judge it solely by criteria intrinsic to its own mode of being. (1971:26)

This article focuses on (a) studying the character development of Florentino Arriza throughout the plot by focusing on the transformation of his innocent character into an indecent character based on the stages of his character development (b) finding out the factors that influence Florentino's character development.

\section{THEORIES ON CHARACTER AND CHARACTERIZATION}

Abrams explains that characters are the persons in a literary work that have moral and dispositional qualities, which are the natural qualities of a person's character.

Characters are the persons presented in a dramatic or narrative work, who are interpreted by the reader as being endowed with moral and dispositional qualities that are expressed in what they say - the dialogue - and by what they do - the action. The grounds in a character's temperament and moral nature for his speech and actions constitute his motivation. (1971:20)

However, in some fictions, the characters may not be persons, Griffith (1986) states that they can be aliens, animals, or artificial intelligences. Inanimate objects are up to the task as well, though they require the author giving them human abilities and psychological traits. Since the actors in a story are usually human, in his book, Foster (1953) is likely to entitle the discussion of characters with the term 'people'.

Foster (1953) also introduces the popular terms to distinguish two forms of characters, flat and round character. A flat character is built around "a single idea or quality" and presented in an outline and without much individualizing detail, and can be fairly adequately described in a single phrase or sentence. A round character, on the other hand, is complex in temperament and motivation and is represented with subtle particularity; thus he is as difficult to describe with any adequacy as a person in real life, and, like most people, he is unpredictable and capable of surprising the readers.

Furthermore, Abrams (1971) states that a character may remain essentially "stable," 
or unchanged in his outlook and dispositions, from the beginning to the end of the work, or he may undergo a radical change, either through a gradual development or as the result of an extreme crisis. His ideas are supported by Griffith (1986). Who classifies characters into two groups of characters, dynamic and static characters. Dynamic characters are characters that change significantly during the story. The changes include the change in insight, commitment, values, circumstance, and all the changes that result in some changes within the character's self. On the other hand, static characters are characters that do not experience significant changes throughout the story. Whether a character remains the same or changes, the readers require "consistency" in a character - he should not suddenly break off and act in a way not plausibly grounded in his temperament as the readers already have come to know it.

Characterization is the action or process of characterizing. It is the way an author presents characters. In direct presentation, a character is described by the author, the narrator or the other characters. In indirect presentation, a character's traits are revealed by action and speech. (http://academic.brooklyn. cuny. edu/english DOD March 7, 2012, 2.04 $\mathrm{PM})$. It can be said that characterization is the process of creating and developing characters in a work of fiction. Through the characterization, it is possible for readers to observe and analyze various aspects of characters, for example, the appearance, age, social status, marital status, gender, educational level, occupation, financial status, religious belief, motivation, sexual orientation, personality etc.

\section{FOUR TEMPERAMENTS THEORY}

To understand more about the personality of the characters, a theory from psychology is needed in this research to support the analysis. It will help to define the temperament that will ifluence the personality of the characters in the novel. Because of that, Galen's theory is chosen as the guidance to classify the personality of the characters. As Cocoris presents in his review, Claudius Galen is popular with his Four Temperament Theory that classifies human's temperaments into four categories: Choleric, Sanguine, Phlegmatic, and Melancholy. (Taken from http://www.zephyrus. co.uk/galen.html on Wednesday, March 07, 2012 at $03.03 \mathrm{pm}$ ). The elaboration of the four categories of human temperaments are as follow:

a. The Choleric is an extroverted, hot-tem pered, quick thinking, active, practical, strong-willed and easily annoyed person. The choleric is self confident, self-suffi cient and very independent minded. They tend to leave little room for negotiation. The choleric is a visionary and seems to never run out of ideas,plans and goals, which are usually very practical. They are slow to build relationship because results tend to be more important than people. They do not easily empathize with the feelings of others or show compassion. Choleric people think big and seek positions of authority.

b. The Sanguine is an extroverted, fun-loving, activity-prone, impulsive, entertaining, persuasive, easily amused, and optimistic person. They are receptive and open to others and build relationships quickly. They are animated, excited and accepting others. They will smile and talk easily and often. Sanguines people are people-oriented that they easily forget about time and are often late arriving at their destination. The Sanguine can change their focus or interest in an instant. They are competitive and tend to be disorganized. The Sanguine is very effective working with people.

c. The Phlegmatic is an introverted, calm, unemotional, and easygoing person. Phlegmatics are both slow and indirect 
when responding to others. They are by far the easiest person with whom one can get along. They live a quiet, routine, life, free of the normal anxieties and stresses of the other temperaments. The Phlegmatic will avoid getting too involved with people and life in general. They show little emotion and are prone to be a grudge holder. They tend to avoid conflicts and making decisions of any kind. They are practical, concrete and traditional thinkers. Phlegmatic people are persistent and consistent at whatever they undertake.

d. The Melancholy is an introverted, logical, analytical, factual, and private people. They respond to others in a slow, cautious and indirect manner. They are timid and may appear unsure and have a serious expression. They are self-sacrificing, gifted and they tend to be a perfectionist. Melancholy people are very sensitive to what others think about their work. They are well organized, and they need reassurance, feedback, and reasons why they should do something. They need information, time to think and a plan. They also fear taking risks, making wrong decisions and being viewed as in competent. Melancholies are skeptical about almost everything but they are crea tive and capable. They tend to get bored with something once they get it figured out. (Taken from http://fourtemperaments. com/Description.htm on Wednes day, March 07, 2012 at $03.01 \mathrm{pm}$ )

\section{THE RELATION BETWEEN PLOT AND CHARACTERS}

According to Abrams (1971), plot is defined as the structure of actions in a dramatic or narrative work, which is ordered and rendered toward achieving particular emotional and artistic effects. The actions are performed by particular characters in a work, and are the means by which they exhibit their moral and dispositional qualities.

Plot and character are two interdependent critical concepts. Plot can be developed because there are events and actions involving the characters in it. On the other hand, the characterization of the characters can be analyzed from the several actions and behaviors, which are told consecutively throughout the plot.

In addition, character development is the term to reveal the progress of a character's self during the story, from the beginning until the end of the story. It can be said that character development is the change of characterization of the dynamic character.

\section{CHARACTER DEVELOPMENT OF FLORENTINO ARIZA}

Based on Galen's theory on four types of temperament that has been explained in the previous discussion, Florentino Arriza can be classified as a melancholy. He matches the description of a melancholy, which is fundamentally introverted, logical, analitical, factual, private and thoughtful. Melancholic people respond to others in a slow, cautious, and indirect manner. They are self-sacrificing, gifted (having a lot of natural ability or intelligence), and they tend to be a perfectionist. Melancholies are very sensitive and can be easily worried about events in their lives. Cocoris explains that Melancholies are reserved and suspicious until they are sure of people's intentions. They will probe for the hidden meaning behind somebody's words. They are timid and may appear unsure and have a serious expression. Melancholies will ask specific questions and sometimes they will repeat the same question just to convince themselves. They need reassurance, feedback, and reasons why they should do something. Melancholies tend to have a negative attitude toward something new until they have had time to think it over. The other negative attitude of Melan- 
choly, they can be preoccupied with the tragedy and cruelty in this world and they can get so involved in one thing then forget to think of other things. In this point, the way Florentino lives his life after Fermina rejects his love is the proof of that explanation. He becomes so miserable and only focuses on his love matter without caring about other things in his life. On the other hand, many facts show the positive side of Melancholies. they can be highly creative in activities such as poetry and art. Below are the description, explanation, and the evidences supporting the idea that Florentino's temperament belongs to the Melancholic type.

It begins from the background information of Florentino Arriza, a son to Transito Arriza. He was born of an occasional alliance with the well-known ship-owner Don Pius V Loayza. Although his father always took care of his expenses in secret, he never recognized him as his son before the law, nor did he leave him with his future secured, causing Florentino Ariza to use only his mother's name even though his true parentage was always common knowledge. Florentino was ten years old when his father passed away. Because of that reason, he had to leave school and went to work as an apprentice in the Postal Agency, where he was in charge of opening sacks, sorting letters, and notifying the public that their letters had arrived. (Marquez, 43)

Florentino grew as a boy with a good sense and it attracted people's sympathy. $\mathrm{He}$ was very thin, with Indian hair plastered down with scented pomade and eyeglasses for myopia, which added to his forlorn appearance. The young Florentino was the sought-after man in his circle, the one who knew how to dance the latest dances and recite sentimental poetry by heart, and who was always willing to play violin serenades to his friends' sweethearts. He was an innocent boy before he fall in love. It is stated in the novel that the day he met Fermina Daza is the day when his inno- cence came to an end (Marquez: 44). He met Fermina Daza when he delivered a telegram to Fermina's father, Lorenzo Daza. Starting from that day, he could not stop thinking of her.

It was in this innocent way that Florentino Ariza began his secret life as a solitary hunter. From seven o'clock in the morning, he sat on the most hidden bench in the little park, pretending to read a book of verse in the shade of the almond trees, until he saw the impossible maiden walk by in her blue-stripped uniform, stockings that reached to her knees, masculine laced oxford, and a single thick braid with a bow at the end, which hung down her back to her waist...Little by little he idealized her, endowing her with improbable virtues and imaginary sentiments, and after two weeks he thought of nothing else but her. (Marquez: 45)

The quotation above shows how his feeling toward Fermina Daza started to drive him crazy and he could not think about other things. He decided to send Fermina a letter but he had no courage to give it to her. While he was thinking how he would give it to her, he wrote several more pages before going to bed, so that the original letter turned to be a dictionary of compliments.

By the time the letter contained more than sixty pages written on both sides, Florentino Ariza could no longer endure the weight of his secret, and he unburdened himself to his mother, the only person with whom he allowed himself any confidences. Transito Ariza was moved to tears by her son's innocence in matters of love, and she tried to guide him with her own knowledge. (Marquez: 46)

Florentino's feeling toward Fermina is so unbearable that he expressed it in writing. as seen in the quotation above the books he had learned by heart inspired his writing. It shows his innocence and confusion in matters of love. It also shows that he was a very melancholic and romantic person who has the ability in expressing his feeling beautifully through words. Later the readers would know 
that in the middle of the story, Florentino Ariza in his middle age became a consultant in making love letters.

His love to Fermina really made him insane. After he gave her the letter, he was so afraid that Fermina would reject his love. $\mathrm{He}$ got sick. In Chapter 2 of the novel, it is told that Florentino was so ill from worry that Fermina would not respond to his declaration of love. His mother called on his godfather, a homeopath, who initially mistakes Florentino's lovesickness for cholera.

Florentino Ariza lost his logic. Again in Chapter 2 of the novel, it is described that Florentino complicated his emotional pain with physical agony when he vomited after eating flowers and drinking cologne so that he might know Fermina's scent. Florentino's illness, it can be argued, transcends the physical to the psychological, for though he is sick in his heart and in his stomach, he is compulsively obsessed, and therefore mentally disturbed. (SparkNotes Editors)

After knowing that Fermina requited his love, his madness did not stop. It continued even worse. Not even a single day did he not write a letter for Fermina. It can be seen from how his mother was very worried about him by using strong words for example, "You are going to wear out your brains" and "No woman is worth all that". Florentino played solo violin from the hill not far from Fermina's house as her lullaby. One day he was jailed for wandering at dawn when war was still continuing. The military patrol suspected him as a spy who sent the messages to the enemy in the key of G with his music. Florentino's response for this incident shows how his love for Fermina had controlled his mind. "What the hell do you mean, a spy?" said Florentino Ariza. "I'm nothing but a poor lover" (Marquez: 58). He thought he was the only man who for three nights slept with irons around his ankles in the cells of the local garrison for the sake of love. He felt martyred for serenading Fermina with his violin and he was so proud of that.
The positive impact of being in love with Fermina is shown in his work. Requited love had given him a confidence and strength he had never known before, and he was so efficient in his work that his boss named him his permanent assistant (Marquez: 61). It proves Galen's theory (Cocoris, 2006) in the previous chapter that a Melancholy is well organized. The Melancholy is determined to make the right and best decision.

From all the evidences, it can be concluded that the young Florentino is good and diligent, and is a man who has a good sense in socializing. He views love as something beautiful that needs lots of sacrifice and courage in order to get it. He views love from the ideal point of view - that love is beautiful, everlasting, and unbreakable - as many poets have described. When he falls in love, it takes all in him. It can be assumed that he is a man who follows his heart rather than his logic.

After two years in a backstreet relationship via letter, hidden from Fermina's father, Florentino Ariza intended to marry Fermina. After being doubted for several months, Fermina finally accepted him to be her future husband. Nevertheless, the story did not go as well. Florentino had to face Fermina's father, Lorenzo Daza who was against his intention to marry Fermina. Lorenzo Daza viewed Florentino as a man without a certain future whose social level was far below his family's level. Florentino in this case could think wisely and act gently. When Lorenzo Daza asked him to end his relationship with Fermina, Florentino with high confidence stood for his intention to marry Fermina and asked Lorenzo Daza for his daughter's hand. "Be that as it may, I cannot answer without knowing what she thinks. It would be a betrayal." said Florentino (Marquez: 67). Here Florentino puts Fermina as the decision maker. He would accept any decision that Fermina chose to make herself happy. He also showed his bravery to fight for his love, this is what he said when Lorenzo Daza 
threatened to shoot hims: "Shoot me. There is no greater glory than to die for love." (Marquez: 68). It proves that love takes all in him. However, although it shows his courage and self-sacrificing to die for love, it also shows his weakness to let love takes his life away.

Florentino was so sad when Lorenzo Daza took his lover away from him. Lorenzo Daza took Fermina in a three years long journey, which is intended to make Fermina forget about Florentino. In fact, he could still write telegraph for Fermina so he did not lose contact with her. Distance and Fermina's absence made his letter stronger than before, he wrote greater promises of love. He promised Fermina to salvage the treasure of sunken galleon for her. He spent most of his time in the lighthouse keeper's shelter, so he could watch over the night at sea from the tower and wrote his love for Fermina.

As the time goes by, Fermina started to realize that it was impossible for them to continue their relationship. The first reason was she could not stand against his father. The second is the journey also made her capable to forget Florentino. Therefore, she told Florentino that their relationship should be ended up. This rejection hit Florentino's heart. The impact of her rejection can be seen in the quotation below,

The real reason was that after Fermina Daza rejected him, when he contracted the fever of many disparate loves in his effort to replace her, it was in the lighthouse and nowhere else that he lived his happiest hours and found the best consolation for his misfortune. (Marquez: 79)

The lines above show that he builds his own world separated from others. He becomes introverted, spending his time alone enjoying his sadness.

The peak of Florentino's broken heart moment is when he learned that Fermina Daza would marry to Dr. Juvenal Urbino, a physician with a family and fortune, educated in
Europe and with an extraordinary reputation for a man of his years. Because of that, Florentino's mother sent Florentino into a journey to make him forget about Fermina Daza. However, it was useless. Florentino Ariza, hardened by so much suffering, attended to the preparations for his journey as if he were a dead man attending to the preparations for his own funeral. (Marquez: 114)

The journey instead of making Florentino Arriza forgot about Fermina Daza, made him so haunted by the memory of Fermina Daza. It is shown in the quotation below,

Florentino Arriza was awake most of the night, thinking that he heard the voice of Fermina Daza in the fresh river breeze, ministering to his solitude with her memory, hearing her sing in the respiration of the boat as it moved like a great animal through the darkness, until the first rosy streaks appeared on the horizon and the new day suddenly broke over deserted pastureland and misty swamps. (Marquez: 116)

Moreover, the journey gives a great change in Florentino Arriza's feeling and personality. He broke his vow to Fermina Daza that he would keep his virginity in the journey. One night when he passed the cabins in the ship, a mysterious woman seized him and pulled him into her cabin. In the darkness, the woman raped him. After that, the woman asked Florentino to go and forget about it. From this experience, Florentino realized that he in fact enjoyed sex very much. It helped him to put aside the memory of Fermina Daza from his mind. Below is the quotation proves the explanation,

This gratifying certainty increased Florentino Ariza's eagerness, for at the height of pleasure he had experienced a revelation that he could not believe, that he even refused to admit, which was that his illusory love for Fermina Daza could be replaced by an earthly passion. (Marquez: 119)

That was the first sexual intercourse that Florentino did. It would be the beginning of 
his next sexual adventures. Started from that moment, Florentino Arriza found a way to make the pain of his unrequited love bearable. Having sex is his painkiller. Some evidences below support this idea,

That supposition was so seductive that he began to think about her with more intensity than he thought about Fermina Daza. (Marquez:121)

Afer six months of furious lovemaking with the Widow Nazaret, Florentino Ariza himself was convinced that he had survived the torment of Fermina Daza. (Marquez:127)

When he realized that he felt happy with her, above all in bed...Sara Noriega, however, achieved the miracle curing him for a time. At least now he could live without seeing Fermina Daza...(Marquez:168)

The joyous and the feeling of relieve that Florentino felt after having sex made his passion to have sex grow bigger and bigger as the time goes by. The terrible fact is he did it with so many women, and he did not care when and where he did that lovemaking. It can be assumed from the evidences below,

And it was just as well. No sooner did he leave his office at five in the afternoon than he began to hunt like a chicken hawk. At first he was content with what the night provided. $\mathrm{He}$ picked up serving girls in the parks, black women in the market, sophisticated young ladies from the interior on the beaches, gringas on the boats from New Orleans. He took them to jetties where half the city also went after nightfall, he took them wherever he could, and sometimes even where he could not, and not infrequently he had to hurry into a dark entryway and do what he could, however he could do it, behind the gate. (Marquez:145)

It was in those days that he devised his rather simplistic theories concerning the relationship between a woman's appereance and her aptitude for love. He distrusted the sensual types, the ones who looked as if they could eat an alligator raw and tended to be the most passive in bed. The type he preferred was just the opposite: those skinny little tadpoles that no one bothered to turn around and look at in the street, who seemed to disappear when they took off their clothes, who made you feel sorry for them when their bones cracked at the first impact, and yet who could leave the man who bragged the most about his virility ready for trashcan. (Marquez: 146)

It is stated in the novel that Florentino had sex with not only single women, widows, or whores, but also married women. It can be concluded that there is a contrast change in Florentino Arriza's characterization between his character in the beginning of the story, in the middle and in the end of the story.

Referring to Foster's theory (1927) on characterization that states that character is divided into two forms, flat and round character, the present writer identifies Florentino Arriza as a round character. Florentino Arriza has a complex temperament and motivation as it is the characteristic of a round character. A round character is as difficult to describe with any adequacy as a person in a real life, and, like most people, he is capable of surprising us. As it has been explained in the previous discussion, in the beginning of the story, Florentino is an innocent and loveable young man. He has sincerity and pure love in his heart. Then his attitude changed because of his broken heart. He becomes a womanizer, using sex as painkiller and does not include love when he does it. His innocence lost in love. However, even though he is a womanizer, Florentino is not merely a bad man or a jerk. He in fact is the victim of love and one thing that must be marked, he never forces any women to have sex with him. All the lovemaking happened based on two side's passion and agreement. Sometimes the women start it first. Below are the quotations supporting the idea,

She came into the room where Florentino Arriza lay reading, and as always she cleaned with great care so as not to disturb him. Then she passed close to bed, and he felt a warm and tender hand low on his belly, (Marquez: 64) 
One night when he stopped his reading earlier than usual and was walking, distracted, toward the toilets, a door opened as he passed through the dining room, and a hand like the talon of a hawk seized him by the shirt sleeve and pulled him into a cabin. In the darkness he could barely see the naked woman... (Marquez: 118)

The quotations above show that Florentino Ariza in some cases became the victim of the situations, which he finally enjoyed. There is something in Florentino that attracts women's sympathy which finally attracted them to come to him. Florentino himself realized his potential and knew well how to attract women to give pleasure to him without offense. It can be assumed from the lines below that Florentino take some advantages from his appearance to attract women,

Florentino Ariza developed methods that seemed incredible in someone like him, taciturn and thin and dressed like an old man from another time. He had two advantages working in his favor..... The other was that women promptly identified him as a solitary man in need of love, a street beggar as humble as whipped dog, who made them yield without conditions, without asking him for anything, without hoping for anything from him except the tranquility of knowing they had done him a favor. (Marquez: 126-127)

It can be assumed that Florentino has lost his innocence but still he looked innocent and it became his weapon to make all the women fell for him. It is stated in the story that he made a notary in a coded book entitled "Women". It contains the list of women he had slept with and until he won back Fermina Daza as the woman of his, he had some twenty-five notebooks, with six hundred twenty-two entries of long-term liaisons, apart from the countless fleeting adventures that did not even deserve a charitable note. (Marquez: 127)

Moreover, based on Griffith theory (1986) that classifies character into two groups, dynamic and static characters, Florentino Ariza belongs to the dynamic characters. Dynamic characters are characters that change significantly throughout the story. The changes include the changes in insight, commitment, values, and even in physical circumstance. All happen in Florentino's character.

\section{FACTORS INFLUENCING FLORENTI- NO'S CHARACTER DEVELOPMENT}

Based on all of the evidences in the story, the present writer eventually recognized the factors that influence Florentino Ariza's character development.

\section{a. Lovesickness and Obsession}

It is assumed Florentino Ariza's love for Fermina Daza is quite dramatic and it should not have been like that. Florentino's love to Fermina is too much and it makes him lost in love and lost his logic. This feeling cannot make him happy, instead it makes him sad because of the unhealthy way in loving. Here is the quotation that supports this idea.

But when he began to wait for the answer to his first letter, his anguish was complicated by diarrhea and green vomit, he became disoriented and suffered from sudden fainting spells and his mother was terrified because his condition did not resemble the turmoil of love so much as devastation of cholera. (Marquez: 50)

It shows how Florentino's response toward the feeling for Fermina is too much. Therefore, he cannot control his body and mind from thinking of her.

Florentino is a man who follows his heart more than his logic. His principle and concept about love finally destructed himself. It can be assumed from the way he positioned love in the most priority in his life. It can be seen from the way he wrote business letters while he worked in his uncle's River Company of the Carribean. He could not make business letters. His words were so flowery. He wrote everything with so much passion that even official documents seemed to be about love. His routine business letters were rhymed and lyrical, no matter how hard he tried to avoid it. 
And when his uncle came to complaint about it, his answer is "Love is the only thing that interests me." (Marquez: 139)

The other evidence is about Florentino's principle that there is no greater death except death for love. He got that inspiration from his biological father, Don Pius V Loayza, who wrote in his notebook long before Florentino was born: The only regret I will have in dying is if it is not for love (Marquez: 140). In fact, Florentino really absorbed that sentence as a principle in his life.

His love turns to an obsession to own Fermina Daza. He cannot let go his love. He keeps it for the rest of his life and thinks of it day and night until it changes to an obsession and possession. Here are the evidences,

Jealousy, which until that time had been drowned in weeping, took possession of his soul. He prayed to God that the lightning of divine justice would strike Fermina Daza as she was about to give her vow of love and obedience to a man who wanted her for his wife only as a social adornment... (Marquez: 121)

The thruth is that he was never the same again. Winning back Fermina Daza was the sole purpose of his life, and he was so certain of achieving it sooner or later that he convinced Transito Ariza to continue with the restoration of the house so it would be ready to receive her whenever the miracle took place. (Marquez: 144)

Moreover, the fact is he kept waiting for Fermina for fifty-three years, seven months, and eleven days and nights. During that period he has made love with different women more than six hundred times. Although finally he got back Fermina Daza, the present writer considers it as not based on love again, but more as an obsession.

\section{b. Environmental Temptation}

If it is tracked back, the beginning of Florentino became a womanizer and sex addict was because he became a victim of a sexu- al assault in the ship when he was in a journey to forget Fermina. For the second lovemaking, it was because Florentino's mother asked Widow Nazaret to sleep over in Florentino's room during the night war. She arranged that situation to make Florentino forget about Fermina and started to have such feeling to Widow Nazaret. For the next lovemakings, as it has been discussed above, Florentino often became the object for women to get satisfaction in sex.

Considering many facts that occurred in Florentino's lovemaking experience, the present writer assumes that it is not only Florentino's passion that makes him a sex addict but also the condition and the situation of his environment, which play a big role in making him to become who he is.

The temptation that he got to have sex and the chances that he always got changed his personality from an innocent young man into an indecent man, and even a womanizer.

\section{CONCLUSION}

Love in time of Cholera presents some internal and external conflicts. It makes the story become dynamic and unpredictable. Nevertheless, with close reading and deep analysis, the present writer can finally find several important points that influence Florentino Ariza's character development.

Florentino Ariza fits the criteria of some of those character forms that have been predicted. He fits the criteria of a round and dynamic character. Florentino Ariza's character development brings a model of a lover whose love can be so harmful if it is not in a healthy portion. Moreover, self-principle and the environments can strongly influence somebody's character.

\section{BIBLIOGRAPHY}

Abrams, M.H. A Glossary of Literary Terms. New York: Holt, Rinehart and Winston, Inc. 1971. 
Forster, E.M. Aspects of the Novel. Cambridge: Trinity College, 1927.

Griffith, Kelly. Writing Essays about Literature: A Guide and Style Sheet. New York: Harcourt Brace Jovanovich, Inc. 1986.

Marquez, Gabriel Garcia. Love in the Time of Cholera. New York: Alfred A Knopf. 1988.
Cocoris, John T. The Temperament Model of Behaviour. http://fourtemperaments.com/Description.htm. fourtemperament Web. accesed March 7. 2012.

SparkNotes Editors. "SparkNote on Love in the Time of Cholera." SparkNotes.com. SparkNotes LLC. n.d.. Web. accesed 17 Jan. 2012.

(http://www/GARCIA/ marquez.htm DOD May 4, 2011,11.55 PM) 